\title{
Critical rainfall thresholds for triggering shallow landslides in the Serchio River Valley (Tuscany, Italy)
}

\author{
R. Giannecchini, Y. Galanti, and G. D'Amato Avanzi \\ Earth Sciences Department, University of Pisa, Italy \\ Correspondence to: Y. Galanti (galanti@dst.unipi.it)
}

Received: 30 August 2011 - Revised: 25 January 2012 - Accepted: 7 February 2012 - Published: 30 March 2012

\begin{abstract}
The Serchio River Valley, in north-western Tuscany, is a well-known tourism area between the Apuan Alps and the Apennines. This area is frequently hit by heavy rainfall, which often triggers shallow landslides, debris flows and debris torrents, sometimes causing damage and death. The assessment of the rainfall thresholds for the initiation of shallow landslides is very important in order to improve forecasting and to arrange efficient alarm systems.

With the aim of defining the critical rainfall thresholds for the Middle Serchio River Valley, a detailed analysis of the main rainstorm events was carried out. The hourly rainfall recorded by three rain gauges in the 1935-2010 interval was analysed and compared with the occurrence of shallow landslides. The rainfall thresholds were defined in terms of mean intensity $I$, rainfall duration $D$, and normalized using the mean annual precipitation. Some attempts were also carried out to analyze the role of rainfall prior to the damaging events. Finally, the rainfall threshold curves obtained for the study area were compared with the local, regional and global curves proposed by various authors. The results of this analysis suggest that in the study area landslide activity initiation requires a higher amount of rainfall and greater intensity than elsewhere.
\end{abstract}

\section{Introduction}

Intense or prolonged rainfall events often cause considerable landslides, floods, damage and casualties, as frequently happens in Northern Tuscany. The Serchio River Valley is situated between the Apuan Alps to the W-SW and the TuscanEmilian Apennines to the E-NE (Fig. 1). The main peaks reach almost $2000 \mathrm{~m}$ a.s.l., while the valley bottom is about 30-100 m a.s.l. (Fig. 2).
Heavy rainfall events characterize the Middle Serchio River Valley (MSRV), where the mean annual precipitation (MAP) is between 1300 and $1700 \mathrm{~mm}$ and can exceed $3000 \mathrm{~mm}$ in the Apuan Alps (Fig. 3). In several cases, intense rainstorms striking the study area have triggered many shallow landslides (mainly soil slips, debris flows), which have exposed the local population to risk.

Shallow landslides typically involve a small volume of earth and/or debris, but are characterized by high velocity and high impact energy. Furthermore, during intense rainstorms many shallow landslides initiate almost simultaneously. Some shallow landslides often direct towards streams, increasing the torrent load. As an example, on 20 November 2000 heavy rainfall hit the MSRV, inducing around 150 failures (Fig. 4) and killing 5 people. Other rainstorms occurred on 20 January 2009, 24 December 2009 and 19 June 2010, triggering many shallow landslides that caused severe damage to buildings and infrastructures. The shallow landslides often affect the road network, generally due to a lack or deficiency of surface water draining systems, which is a recurrent case in many regions of the world (Anderson 1983; Haigh et al., 1993; Larsen and Parks 1997; D'Amato Avanzi et al., 2012). For example, during the 24 December 2009 rainstorm 132 landslides affected the roads: 22 occurred along the main roads, the other 110 along local ones. This generally blocks traffic, often isolating villages and stopping productive activities (D'Amato Avanzi et al., 2012).

The definition of rainfall thresholds for the initiation of shallow landslides can provide a crucial decision-making tool in risk management. In the relevant literature, two approaches have been proposed for evaluating the relationship between rainfall and landslide occurrence. The first approach is based on physical, process-based models (Montgomery and Dietrich, 1994; Wilson and Wieckzorek, 1995; Wu and Sidle, 1995; Iverson, 2000; Crosta and Frattini, 2003), whereas the second approach relies on the definition of 


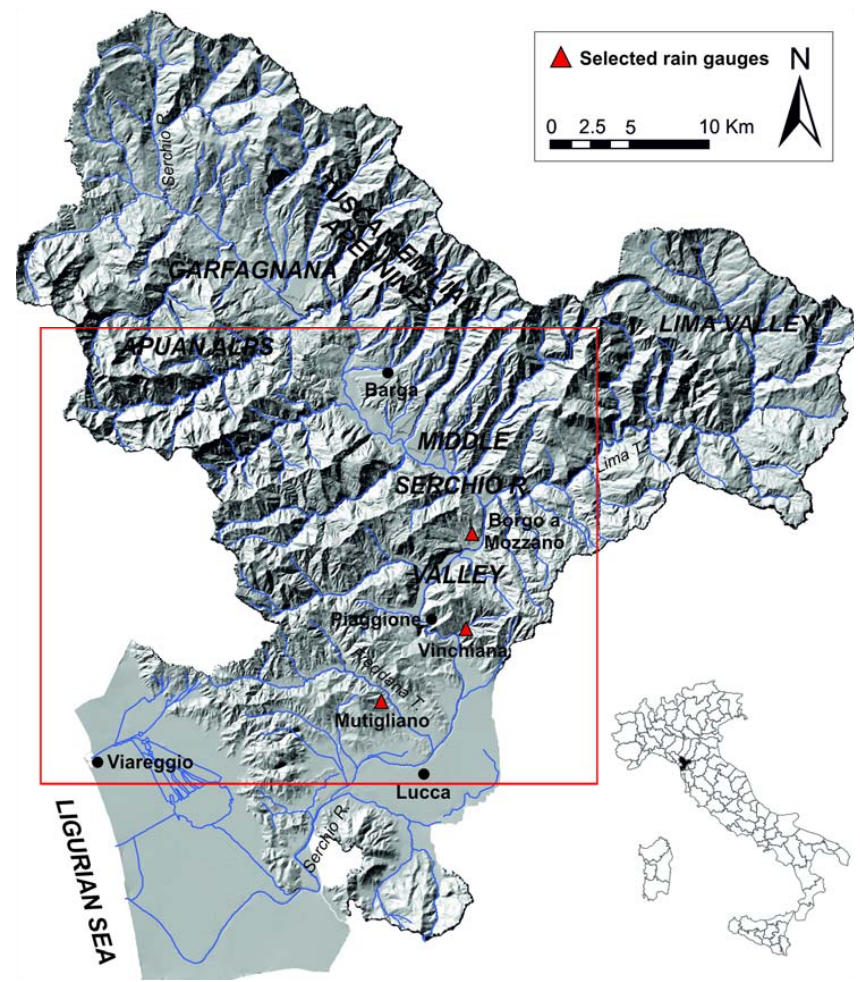

Fig. 1. Map of the Serchio River Valley and location of the three selected rain gauges. Red rectangle shows the Middle Serchio R. Valley.

empirical thresholds (Caine, 1980; Reichenbach et al., 1998; Corominas, 2000; Aleotti, 2004; Wieczorek and Glade, 2005; Giannecchini, 2006; Guzzetti et al., 2007, 2008; Cannon et al., 2008; Dahal and Hasegawa, 2008, Brunetti et al., 2010; Saito et al., 2010).

The physical models generally require numerous and expensive geotechnical characterization of the materials involved in landsliding, and therefore may be applied only in restricted areas.

The empirical approach can be classified according to the geographical extent over which the critical thresholds are defined (i.e. global, national, regional or local) and by the type of rainfall information used to determine the threshold (Guzzetti et al., 2007, 2008).

Rainfall duration $D$, rainfall intensity $I$, cumulative event rainfall $E$, and antecedent rainfall $A(D)$ are the most commonly investigated variables. In particular, landslide initiation is frequently related to rainfall intensity and duration (Caine, 1980; Aleotti, 2004; Giannecchini, 2006; Guzzetti et al., 2007, 2008; Cannon et al., 2008; Coe et al., 2008; Dahal and Hasegawa, 2008). Antecedent rainfall, geological and climatic context play important roles in triggering landslides, but the rate of water infiltration and its movement below the surface are the key aspects of landslide initiation and are considered in physically based, process driven methods (Caine,

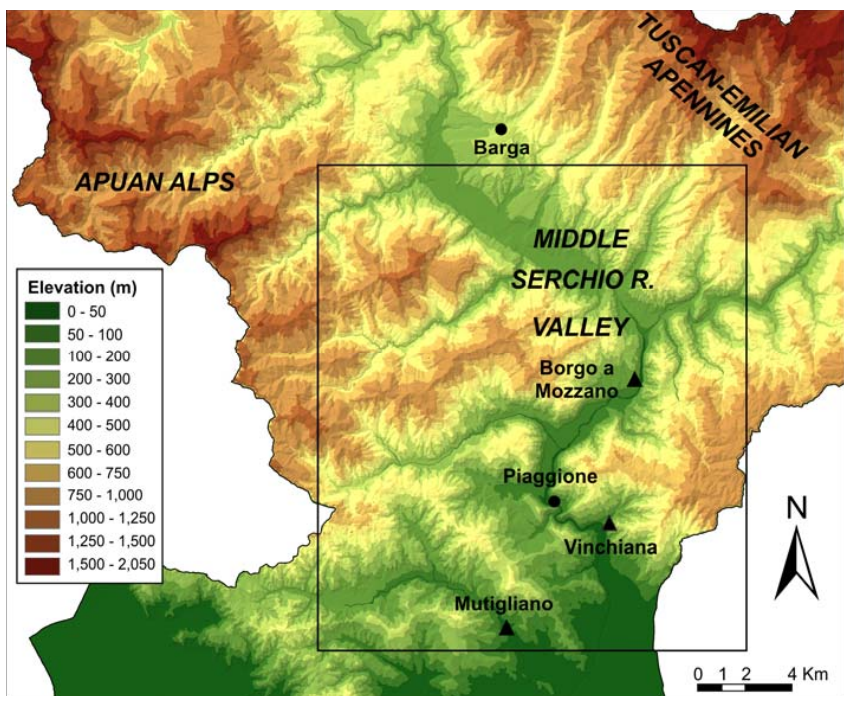

Fig. 2. Map of MSRV. Shades of colour show elevation, from $5 \times 5 \mathrm{~m}$ DEM. Black triangles show location of the 3 considered rain gauges. The black frame shows the study area. DEM: courtesy of the Authority of the Serchio River Basin.

1980; Reichenbach et al., 1998; Iverson, 2000; Crosta and Frattini, 2003; Giannecchini et al., 2007; D'Amato Avanzi et al., 2009). The empirical approach avoids quantifying the numerous parameters needed by the physically-based models. It could be used in applying physically-based approaches.

The mathematical or statistical criteria used in defining critical rainfall thresholds are not usually specified in the literature, except in rare cases, as in Guzzetti et al.'s reviews $(2007,2008)$. A rainfall threshold is generally obtained on a linear or logarithmic-scale graph by drawing the differentiation line between the rainfall features (e.g. rainfall duration and intensity) that cause landslides and those that do not or by drawing the lower boundary of the rainfall features resulting in failures. Recently, some authors (Guzzetti et al., 2007, 2008; Brunetti et al., 2010; Saito et al., 2010), criticizing the above-mentioned approaches due to their lack of objectivity and repeatability, have introduced some statistical methods for the definition of more objective rainfall intensity-duration (ID) thresholds. A first method is based on a probabilistic approach ("Bayesian inference method") and can be used to determine the minimum-ID threshold for the initiation of landslides (Guzzetti et al., 2007, 2008; Brunetti et al., 2010). Brunetti et al. (2010) also adopts a "Frequentist" approach in order to determine the intercept $\alpha$ and the slope $\beta$ of the power law curve selected to represent the rainfall threshold. Other statistical criteria use quantile regression to determine the ID thresholds objectively (Saito et al., 2010). In order to define the minimum-ID rainfall thresholds, a quantile regression may be performed for some percentiles, for example in the 2 nd and 5 th percentiles of the rainfall events dataset. 


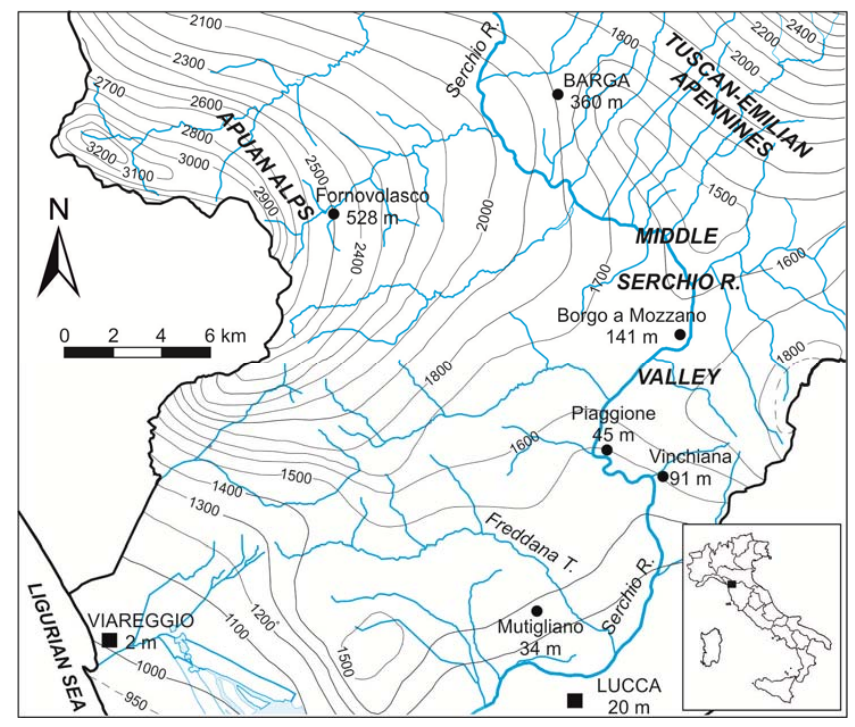

Fig. 3. Isohyet map of the MSRV for the 1951-1981 interval (after Baldacci et al., 1993, modified).

In this work, the hourly rainfalls recorded by three rain gauges (Borgo a Mozzano from 1942 to 2010, Mutigliano from 1937 to 2010 and Vinchiana from 1964 to 2010) of the MSRV were analyzed and compared with the occurrence of shallow landslides involving homogeneous areas in terms of geological, geomorphologic and climatic features.

In accordance with more traditional methods (Giannecchini, 2006 and reference therein), the rainfall thresholds and the normalized rainfall thresholds were obtained using manual fitting methods by determining a differentiation line of the dataset, including rainfall conditions that did or did not result in landslides. Considering the fragility of the study area, the possibility of obtaining and managing more cautionary rainfall thresholds prompted the use of manual fitting.

\section{Study area}

The MSRV is situated between the Apuan Alps to W-SW and the Apennine chain to E-NE (Fig. 2). It falls within the Northern Apennines, a fold-and-thrust belt formed during the Upper Cretaceous-Upper Miocene. From the Upper Miocene, the tensional tectonics gave origin to tectonic depressions bounded by NW-SE trending normal faults, in which either marine or continental successions were deposited. From top to bottom, the Ottone unit, the Canetolo unit, and the Tuscan Nappe crop out. These originated in different paleogeographic domains: the Ligurian, the Sub-Ligurian and Tuscan domains, respectively (Elter et al., 1975; Carmignani and Kligfield 1990; Carmignani et al., 2000; Puccinelli et al., 2012). Pliocene and Quaternary continental deposits extensively cover the slopes.

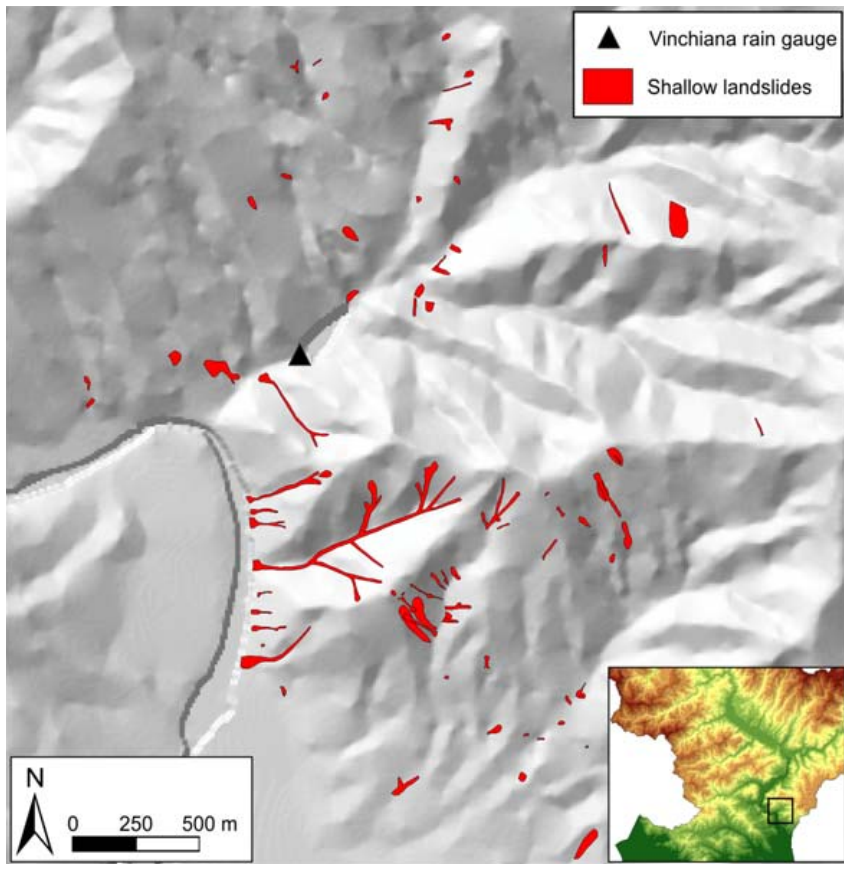

Fig. 4. Sketch map of the main shallow landslides triggered during the 20 November 2000 rainstorm in the Vinchiana area.

The morphology is highly influenced by the geological and structural features. NW-SE trending normal faults delineate the fundamental configuration of the Serchio River Valley, which can be considered as a consequent valley, adapted to the tectonic structure. The uplift movements of the late orogenic stages determined relevant height differences, while the fluvial and slope processes shaped the landscape. Glacial processes involved the higher areas close to the main watershed (Castaldini et al., 2004).

The climatic conditions of the MSRV are directly related to the geographical and morphological features. The mountains intercept Atlantic and Mediterranean humid air masses, forcing adiabatic ascent and subsequent condensation, which results in heavy precipitation events. The rainfall regime of the MSRV can be ascribed to the Apennine-Mediterranean type with transition to the sub-coastal type. It is characterised by dry summers and cold winters, with a primary peak of rainfall in autumn and a secondary maximum in spring. The mean annual rainfall depends on the altitude. It ranges from $1300 \mathrm{~mm}$ of the valley floor to about $1800 \mathrm{~mm}$ at higher altitudes (Fig. 3, Baldacci et al., 1993).

Intense rainstorms are quite frequent and can trigger a lot of shallow landslides, mostly involving the colluvium and debris deposits of the Macigno Fm. (Tuscan Nappe). This formation underlies about $35 \%$ of the study area. It consists of siliciclastic turbidites made of grey-brown sandstone and normally shows a high sandstone/shale ratio and thick to very thick, coarse-grained strata. Based on Bieniawski's (1989) Rock Mass Rating, the Macigno Fm. 

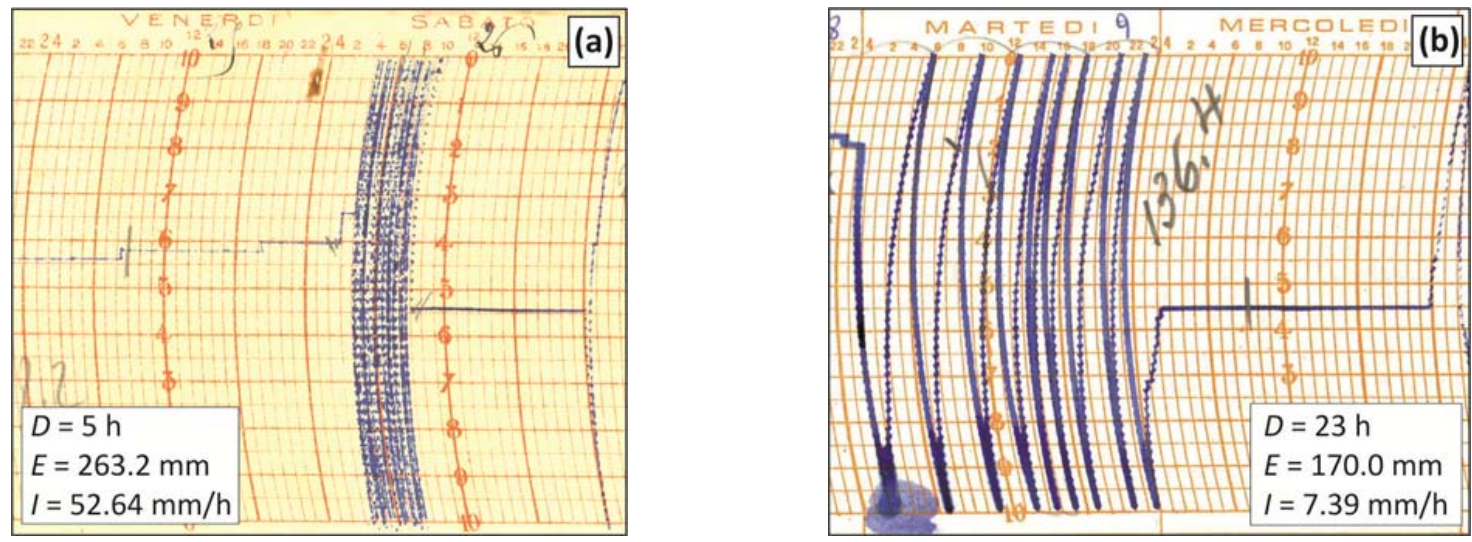

Fig. 5. Examples of pluviograph charts ( $D$ : rainfall duration; $E$ : cumulative event rainfall; $I$ : rainfall intensity): record of the 26 September 1942 rainstorm in the Borgo a Mozzano area (a); record of the 9 January 1979 rainstorm in the Mutigliano area (b).

can be typically described as a stratified medium strong rock, intersected by orthogonal, NW and SE trending joint sets. The joint sets are closely spaced, very persistent, open, smooth or slightly rough, from moderately to highly weathered and dry to damp. Infilling is not very significant. The basic Rock Mass Rating is of about 35 (poor rock). Intense deformation and fracturing of the rock, together with chemical alteration, lead to a considerable production of debris and colluvium. These deposits consist of sand and gravel with a minor part of finer materials (silt and clay) and can mantle vast slopes, with a thickness commonly between $0.5 \mathrm{~m}$ and 2-3 m.

The shallow landslides considered here can be classified as complex, rapid to extremely rapid debris slide-debris flows (Cruden and Varnes, 1996) and are also known as soil slipdebris flows, or simply debris flows (Campbell, 1975). They commonly involve the entire thickness of the slope deposit, up to an impermeable or less permeable bedrock (mostly consisting of the Macigno Fm.). A thin portion (0.5-1 m) of highly weathered bedrock may also be involved. Afterwards, the material usually flows into the riverbeds and quickly reaches the main valley bottom, where the reduced slope gradient induces deposition and stops the flowing mass.

\section{Methodology}

The main rainfall events recorded by three rain gauges in the MSRV (Figs. 1 and 2) were analysed with the goal of defining the rainfall thresholds for the initiation of shallow landslides.

The analysis of rainfall events shorter than $24 \mathrm{~h}$ requires hourly rainfall data. Therefore it considered different operating periods for the three rain gauges: from 1935 to 2010 for the Mutigliano rain gauge ( $34 \mathrm{~m}$ a.s.l.), from 1942 to 2010 for the Borgo a Mozzano rain gauge (141 m a.s.1.), and from 1964 to 2010 for the Vinchiana rain gauge (91 m a.s.l.).
Despite different operating periods of the rain gauges analyzed, these stations are believed to be the most effective for the analysis. They are quite close together, since $12 \mathrm{~km}$ separate the Mutigliano and Borgo a Mozzano rain gauges, while the Vinchiana one is exactly halfway between them (Figs. 1 and 2).

The rain gauges were equipped with pluviographs until 2000. In 2000 the Borgo a Mozzano and Mutigliano rain gauges were equipped with electronic rain gauges, while the Vinchiana rain gauge was replaced by an electronic one about $2 \mathrm{~km}$ away (near the village of Piaggione, $45 \mathrm{~m}$ a.s.l.).

The mean annual precipitation (MAP) was calculated for the whole recording time of the stations, including the period of both daily and hourly recording. The MAP for each instrument increases with altitude: $1331 \mathrm{~mm}$ at Mutigliano, $1376 \mathrm{~mm}$ at Vinchiana and $1565 \mathrm{~mm}$ at Borgo a Mozzano.

During the period considered in this research, 335 rainfall events were analysed on the basis of the combination of rainfall duration $D$ and cumulative rainfall $E$. From 1942 onwards, 97 events were recorded by at least two rain gauges. Since 1964, 29 events have been recorded in all the rain gauges. Altogether 490 rainfall records were analyzed (195 at Borgo a Mozzano, 155 at Mutigliano, and 140 at Vinchiana).

Each event was evaluated on the basis of the pluviograph data (Fig. 5). For example, events with low duration (1$2 \mathrm{~h}$ ) and high intensity $\left(20-45 \mathrm{~mm} \mathrm{~h}^{-1}\right)$ or high duration (80$100 \mathrm{~h})$ and low intensity $\left(1.5-3 \mathrm{~mm} \mathrm{~h}^{-1}\right)$ and intermediate events were considered. For each event the following rainfall variables were collected: (i) cumulative rainfall $E(\mathrm{~mm})$, (ii) rainfall duration $D(\mathrm{~h})$, (iii) mean intensity $I\left(\mathrm{~mm} \mathrm{~h}^{-1}\right)$, and (iv) antecedent rainfall $A(D)(\mathrm{mm})$ related to $3,7,15$ and 30 days.

For each rainfall event, a thorough research on its consequences in the study area (number of shallow landslides, damage, deaths) was carried out. Areas of about 10$15 \mathrm{~km}$ around each rain gauge were considered in order 


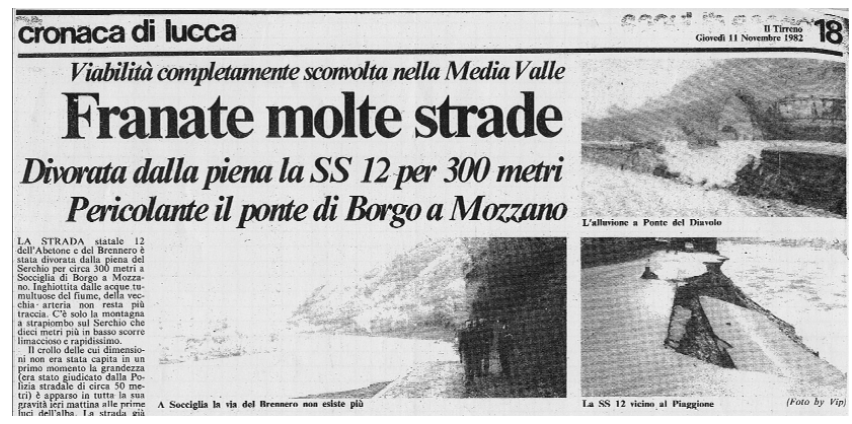

Fig. 6. Example of information coming from a local newspaper. The main title reads: "Many roads affected by landslides" (source: Il Tirreno, 11 November 1982).

Table 1. Frequency of the A, B and $\mathrm{C}$ events at the three rain gauges of the study area (A: events that induced ten or more shallow landslides; B: events that induced less than ten shallow landslides; C: events that did not trigger any landslides). \%: percentage of events that fall in $\mathrm{A}, \mathrm{B}$ and $\mathrm{C}$ group for each considered rain gauge.

\begin{tabular}{lrrrrrrrrr}
\hline Rain gauge & \multicolumn{2}{c}{ A events } & & \multicolumn{2}{c}{ B events } & & \multicolumn{2}{c}{ C events } & Total \\
\cline { 2 - 3 } & no. & $\%$ & & no. & $\%$ & & no. & $\%$ & no. \\
\hline Borgo a Mozzano & 5 & 3 & & 35 & 18 & & 155 & 79 & 195 \\
Mutigliano & 5 & 3 & & 25 & 16 & & 125 & 81 & 155 \\
Vinchiana & 6 & 4 & & 26 & 19 & & 108 & 77 & 140 \\
\hline
\end{tabular}

to find possible consequences of the rainfall events. Different sources of information were analysed including: (i) archives of the local municipal councils, (ii) scientific papers, (iii) technical reports, (iv) regional and local newspapers, and (v) information provided by local inhabitants. However, most of the information came from local newspapers (Fig. 6).

The rainfall events investigated were subdivided into three groups on the basis of the consequences induced on the territory and gathered by the archive research. Since the 1980s, rainfall events can be discriminated on a quantitative basis: (i) events that induced ten or more shallow landslides (A events, in the following tables and graphs), (ii) events that induced less than ten shallow landslides (B events); and (iii) events that did not trigger any landslides, including those events for which no information on consequences was found in archives and newspapers (C events). Before the 1980s, information about the number and consequences of landslides are often confused and incomplete. Therefore, on the basis of qualitative descriptions reported by newspapers and documents, events that induced several landslides have been included in the A-type, while events that only locally induced few landslides have been considered as B-type. For the A events, information on the effects is very clear. For example, during the 20 November 2000 heavy rainstorm approximately 150 shallow landslides occurred, causing 5 fatalities. Table 1 shows number and frequency of A, B and C-type events for each rain gauge.
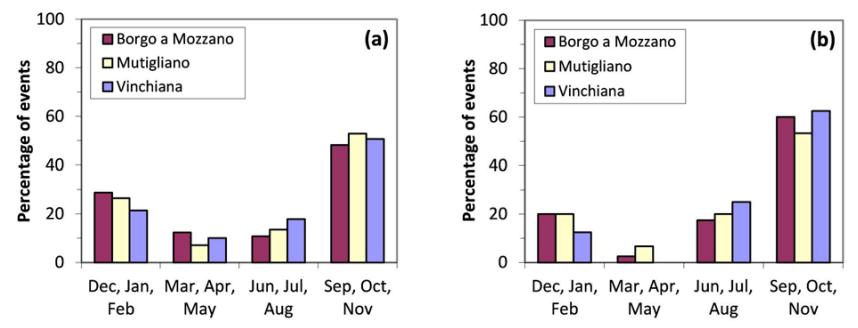

Fig. 7. Seasonal distribution of the main rainstorms occurring in the MSRV from 1935 to 2010, recorded at the Borgo a Mozzano, Mutigliano and Vinchiana rain gauges: (a) distribution of all the rainstorms analysed; (b) distribution of the rainstorms inducing shallow landslides.

\section{Critical threshold analysis}

\subsection{Intensity-duration thresholds}

In the 1935-2010 period the rain gauges recorded many rainfall events: 195 at Borgo a Mozzano, 155 at Mutigliano, and 140 at Vinchiana. Most of them were recorded by all three rain gauges.

The research highlighted that very heavy rainstorms occurred: on 25 November 1990, 20 November 2000, and 19 June 2010 in the Vinchiana area, on 26 September 1942, 21 September 1994, and 20 January 2009 in the Borgo a Mozzano area, and on 9 January 1979, 9 June 1992, and 5 October 1998 in the Mutigliano area. With reference to the seasonal distribution, the analyzed rainstorm events preferentially occurred in autumn (almost 50\% in the SeptemberNovember period, Fig. 7), the rainiest season in the study area. Giannecchini (2006) found a comparable seasonal distribution for the adjacent Southern Apuan Alps, while Guzzetti (2000) and Guzzetti et al. (2005) obtained similar results on a national scale for rainfall events that caused deaths or missing people. Figure 7 shows the seasonal distribution of all the analysed rainstorms (Fig. 7a) and of those inducing shallow landslides and damage (Fig. 7b). The most severe rainstorms usually occurred between September and November and in the June-August period.

In order to construct the rainfall intensity-duration (ID) thresholds, all the duration $D$ and intensity $I$ data were plotted together on a bi-logarithmic scale ( $D$ on the x-axis, $I$ on the $\mathrm{y}$-axis), where the A, B and C events were also plotted. Then, manual fitting was used to draw the critical threshold curve, i.e. the curves better differentiating the A, B and C events.

Upper and lower threshold curves can be traced. They subdivide the ID field into three parts, including the rainfall conditions of rainstorms which induce different stability conditions (Fig. 8). The rainfall events falling between the two curves should trigger only a few landslides, while those falling above the upper curve should trigger more than ten landslides. Below the lower curves no consequences are expected. 

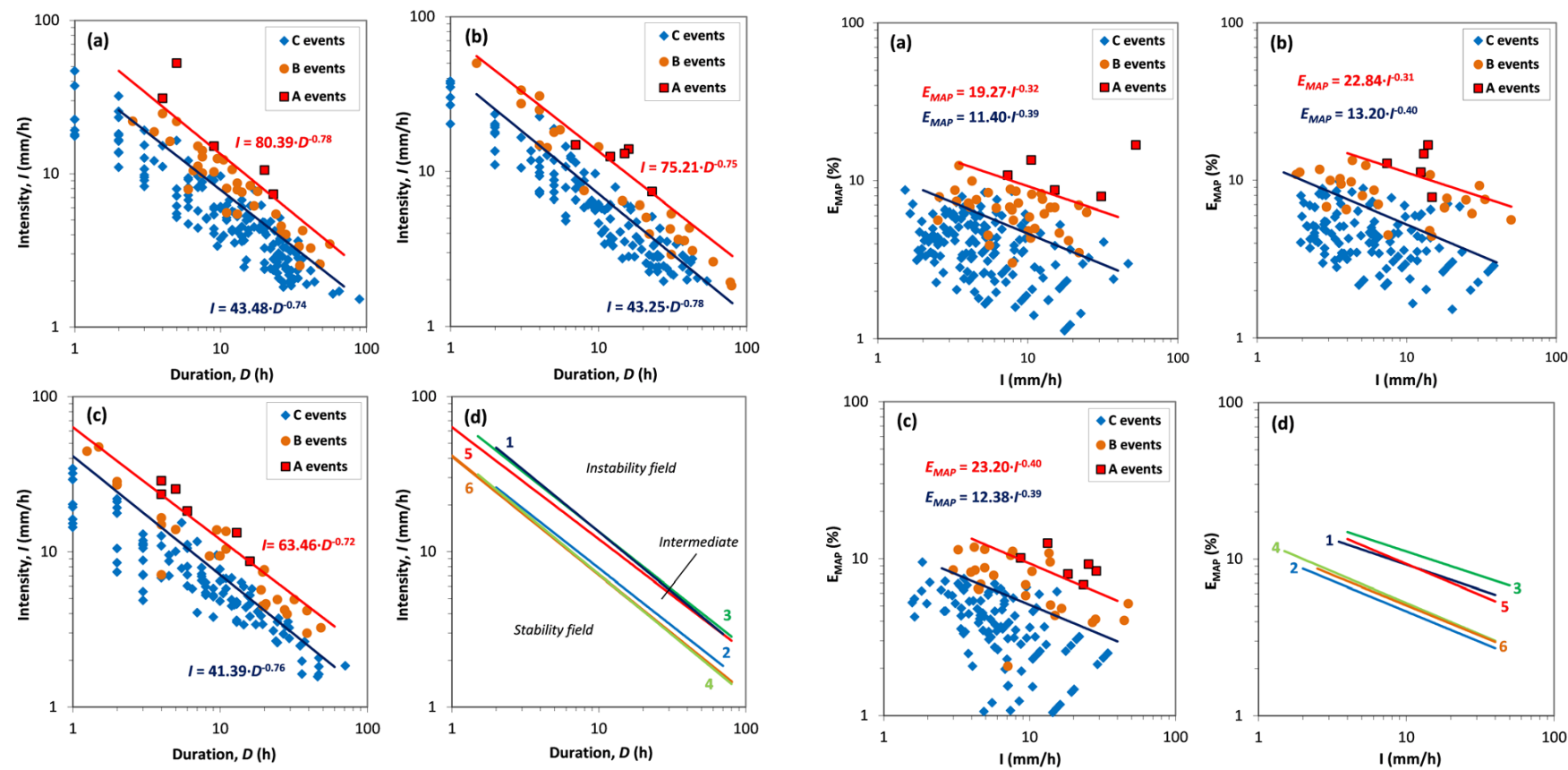

Fig. 8. Intensity-duration correlation for the Borgo a Mozzano (a), Mutigliano (b) and Vinchiana (c) rain gauges. The lower (blue) and upper (red) threshold curves are shown. (d) Comparison between the ID thresholds obtained for the study area. The three stability fields are highlighted; (1) Borgo a Mozzano upper curve; (2) Borgo a Mozzano lower curve; (3) Mutigliano upper curve; (4) Mutigliano lower curve; (5) Vinchiana upper curve; (6) Vinchiana lower curve.

The threshold curves are expressed in the form (Caine, 1980):

$I=\alpha \times D^{-\beta}$

where $I$ is the rainfall intensity $\left(\mathrm{mm} \mathrm{h}^{-1}\right), D$ is the duration of the rainfall event (h), $\alpha$ is the intercept, and $\beta$ defines the slope of the power law curve.

The rainfall thresholds are defined for the range of duration $2<D<70 \mathrm{~h}, 1.5<D<80 \mathrm{~h}$ and $1<D<80 \mathrm{~h}$ for the Borgo a Mozzano, Mutigliano and Vinchiana rain gauges, respectively (Fig. 8; Table 2). Generally the upper thresholds are defined in the range of mean intensity $4<I<60 \mathrm{~mm} \mathrm{~h}^{-1}$, while the lower thresholds are defined in the range of $2<I<40 \mathrm{~mm} \mathrm{~h}^{-1}$ (Fig. 8). Inspection of Fig. 8 indicates that both the upper and lower threshold curves are similar for the three rain gauges.

Rainfall events lasting approximately $10 \mathrm{~h}$ are quite frequent in the study area. Therefore, rainfall durations of both 10 and $24 \mathrm{~h}$ were considered. For a rainfall duration $D$ of $10 \mathrm{~h}$ rainfall intensities are $13.4,13.5$ and $12.0 \mathrm{~mm} \mathrm{~h}^{-1}$ for the Borgo a Mozzano, Mutigliano and Vinchiana upper thresholds (1, 3 and 5 in Fig. 8d, respectively).

For a duration of $24 \mathrm{~h}$, intensities are 6.7, 6.9 and $6.4 \mathrm{~mm} \mathrm{~h}^{-1}$ for the Borgo a Mozzano, Mutigliano and

Fig. 9. Bi-logarithmic $E_{\text {MAP }} I$ correlation for the Borgo a Mozzano (a), Mutigliano (b) and Vinchiana (c) rain gauges. Upper (red) and lower (blue) critical threshold curves are shown. (d) Comparison between the different thresholds; (1) Borgo a Mozzano upper curve; (2) Borgo a Mozzano lower curve; (3) Mutigliano upper curve; (4) Mutigliano lower curve; (5) Vinchiana upper curve; (6) Vinchiana lower curve.

Vinchiana upper thresholds (1, 3 and 5 in Fig. 8d, respectively). The Vinchiana upper threshold is the lowest, i.e. the most conservative for a duration less than $30 \mathrm{~h}$, and especially for short events $(D \leq 10 \mathrm{~h})$.

As regards the lower thresholds (Fig. 8), for a duration of $10 \mathrm{~h}$ the rainfall intensity is $7.8 \mathrm{~mm} \mathrm{~h}^{-1}, 7.2 \mathrm{~mm} \mathrm{~h}^{-1}$, and $7.1 \mathrm{~mm} \mathrm{~h}^{-1}$ at Borgo a Mozzano (2 in Fig. 8d), Mutigliano (4 in Fig. 8d) and Vinchiana (6 in Fig. 8d) rain gauges, respectively. For $D \geq 24 \mathrm{~h}$, the Borgo a Mozzano lower threshold is less conservative.

Figure 8 also shows some misclassifications of the type of events. Some A events fall in the B events field and vice versa. Such exceptions are probably due to uncertainty in the areal extent of the damage, which can often be based only on historical description or information by newspapers. Other misclassifications occur between B and C events. For example, in the Borgo a Mozzano case (Fig. 8a) there are $12.9 \%$ missing events. These missing events are not linkable to definite causes. Occasional and extemporary causes probably add to the triggering rainfall and induce unexpected landslides. Otherwise, bad functioning of the rain gauge could be an alternative cause.

In Fig. 8 the upper and lower threshold curves identify three fields with differing degrees of stability. Below 
Table 2. Rainfall ID thresholds for initiation of shallow landslides for the Borgo a Mozzano, Mutigliano, and Vinchiana rain gauges. Equation: $D$, rainfall duration in hours; $I$, rainfall intensity in $\mathrm{mm} \mathrm{h}^{-1}$. Range: range of validity for the threshold.

\begin{tabular}{llll}
\hline Rain gauge & Type & Equation & Range \\
\hline \multirow{2}{*}{ Borgo a Mozzano } & upper curve & $I=80.39 \times D^{-0.78}$ & $2<D<70$ \\
& lower curve & $I=43.48 \times D^{-0.74}$ & $2<D<70$ \\
Mutigliano & upper curve & $I=75.21 \times D^{-0.75}$ & $1.5<D<80$ \\
& lower curve & $I=43.25 \times D^{-0.78}$ & $1.5<D<80$ \\
Vinchiana & upper curve & $I=63.46 \times D^{-0.72}$ & $1<D<80$ \\
& lower curve & $I=41.39 \times D^{-0.76}$ & $1<D<80$ \\
\hline
\end{tabular}
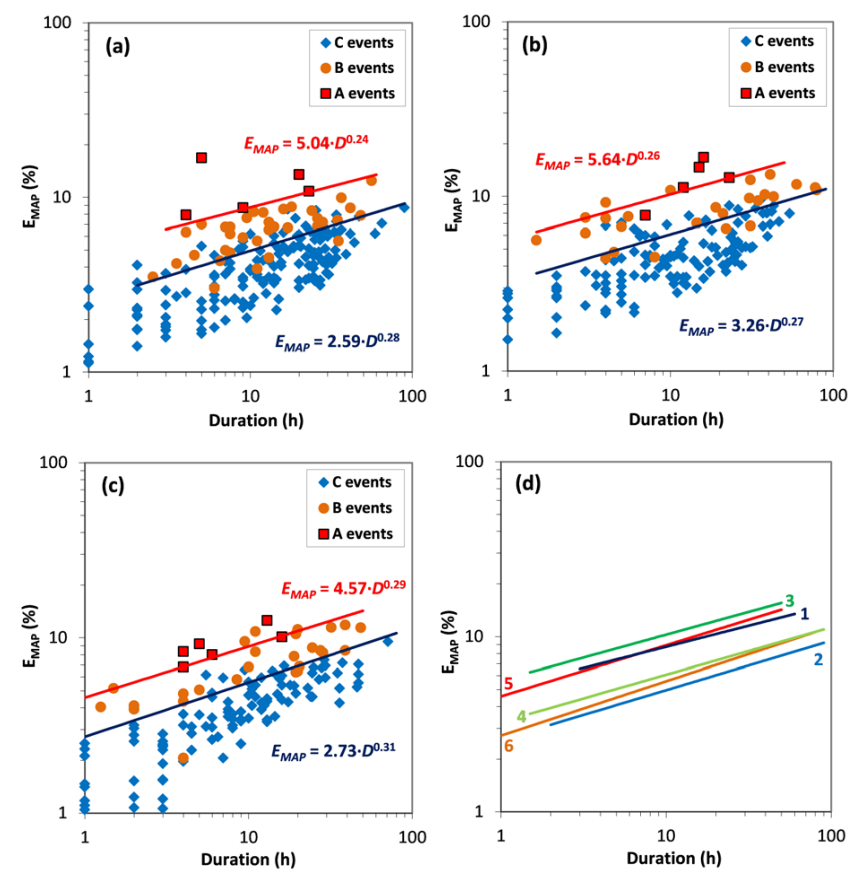

Fig. 10. Bi-logarithmic $E_{\mathrm{MAP}} D$ correlation for Borgo a Mozzano (a), Mutigliano (b) and Vinchiana (c) rain gauges. Upper (red) and lower (blue) critical threshold curves are shown. (d) Comparison between the thresholds; (1) Borgo a Mozzano upper curve; (2) Borgo a Mozzano lower curve; (3) Mutigliano upper curve; (4) Mutigliano lower curve; (5) Vinchiana upper curve; (6) Vinchiana lower curve.

the lower threshold (blue line) stability generally prevails. Above the upper curve (red line) instability prevails, while the field between the two curves includes intermediate or uncertain stability (Fig. 8d). The probability of each A, B or C event to fall within a defined stability field can be estimated. The results are shown in Table 3.

\subsection{Normalization}

Various authors assert that each area is in equilibrium with its rainfall conditions (Guidicini and Iwasa, 1977; Govi and Sorzana, 1980; Cannon, 1988; Bacchini and Zannoni, 2003;
Aleotti, 2004; Giannecchini, 2006). Therefore, in order to normalize the rainfall data, they are commonly compared to the mean annual precipitation (MAP).

The MAP was calculated all through the investigated period for each rain gauge. The MAP was $1565 \mathrm{~mm}$ at Borgo a Mozzano (from 1921 to 2010), $1376 \mathrm{~mm}$ at Vinchiana (from 1930 to 2010), and $1331 \mathrm{~mm}$ at Mutigliano (from 1934 to 2010). The MAP is different for each rain gauge, since it rises with altitude. Guidicini and Iwasa (1977) introduced the normalized event rainfall ( $\left.E_{\mathrm{MAP}}\right)$, i.e. the cumulative event rainfall divided by MAP. Based on this parameter, the relationships $E_{\mathrm{MAP}} I$ and $E_{\mathrm{MAP}} D$ were analysed for each rain gauge (Figs. 9 and 10; Tables 4 and 5).

On the basis of the same empirical approach and manual fitting used for the identification of the ID thresholds, two threshold curves were drawn (Figs. 9, 10). For each rain gauge the bi-logarithmic functions $E_{\mathrm{MAP}}(I)$ and $E_{\mathrm{MAP}}(D)$ describe the thresholds (Tables 4 and 5).

The $E_{\mathrm{MAP}} I$ and the $E_{\mathrm{MAP}} D$ thresholds are expressed by the Eqs. (2) and (3), respectively:

$$
\begin{aligned}
& E_{\mathrm{MAP}}=\alpha \times I^{-\beta} \\
& E_{\mathrm{MAP}}=\alpha \times D^{\beta}
\end{aligned}
$$

where $E_{\mathrm{MAP}}$ is the normalized event rainfall, $I$ is the rainfall intensity (in $\mathrm{mm} \mathrm{h}^{-1}$ ), $D$ is the duration of the rainfall event (in h), $\alpha$ is the intercept, and $\beta$ defines the slope of the power law curve.

Two threshold curves delimit three fields of stability (Figs. 9 and 10): stability generally prevails (below the lower curve), uncertain stability (between the two curves), instability (above the upper curve). Figures 9 and 10 show that some $\mathrm{B}$ events (triggering less than ten shallow landslides) fall below the lower threshold curves. These missing events can be due to occasional and extemporary causes or to bad functioning of the rain gauge.

Inspection of Fig. 9 and Table 4 indicates that the $E_{\mathrm{MAP}}$, the critical amount for triggering shallow landslides, decreases with increasing $I$. The lower thresholds obtained for the three rain gauges are similar. The Borgo a Mozzano lower threshold ( 2 in Fig. 9d) is the most conservative, while the Mutigliano upper threshold ( 3 in Fig. 9d) is higher 
Table 3. Frequency of the A, B and C events in each stability field for the three rain gauges. The percentage of the events falling in the proper field is in bold (theoretically it should be $100 \%$ ).

\begin{tabular}{lcrrrr}
\hline Rain gauge & Event type & No. events & Stability field (\%) & Intermediate (\%) & Instability field (\%) \\
\hline \multirow{4}{*}{ Borgo a Mozzano } & $\mathrm{A}$ & 5 & 0 & 0 & $\mathbf{1 0 0}$ \\
& $\mathrm{B}$ & 35 & 12.9 & $\mathbf{8 7 . 1}$ & 0 \\
& $\mathrm{C}$ & 155 & $\mathbf{8 6 . 5}$ & 13.5 & 0 \\
\hline \multirow{4}{*}{ Mutigliano } & $\mathrm{A}$ & 5 & 0 & 10 & $\mathbf{8 0}$ \\
& $\mathrm{B}$ & 25 & $\mathbf{8 1 . 6}$ & 18.4 & 12 \\
\hline \multirow{3}{*}{ Vinchiana } & $\mathrm{C}$ & 125 & 0 & 0 & $\mathbf{1 0 0}$ \\
& $\mathrm{A}$ & 6 & 3.8 & $\mathbf{8 4 . 7}$ & 11.5 \\
& $\mathrm{~B}$ & 26 & $\mathbf{8 5 . 2}$ & 14.8 & 0 \\
\hline
\end{tabular}

Table 4. $E_{\mathrm{MAP}} I$ thresholds for initiation of shallow landslides for the Borgo a Mozzano, Mutigliano, and Vinchiana rain gauges. Equation: $I$, rainfall intensity in $\mathrm{mm} \mathrm{h}^{-1} ; E_{\mathrm{MAP}}$, cumulative event rainfall normalized by MAP. Range: range of validity for the threshold.

\begin{tabular}{llll}
\hline Rain gauge & Type & Equation & Range \\
\hline \multirow{2}{*}{ Borgo a Mozzano } & upper curve & $E_{\mathrm{MAP}}=19.27 \times I^{-0.32}$ & $3.5<I<40$ \\
& lower curve & $E_{\mathrm{MAP}}=11.40 \times I^{-0.39}$ & $2<I<40$ \\
\multirow{2}{*}{ Mutigliano } & upper curve & $E_{\mathrm{MAP}}=22.84 \times I^{-0.31}$ & $4<I<50$ \\
& lower curve & $E_{\mathrm{MAP}}=13.20 \times I^{-0.40}$ & $1.5<I<40$ \\
Vinchiana & upper curve & $E_{\mathrm{MAP}}=23.20 \times I^{-0.40}$ & $4<I<40$ \\
& lower curve & $E_{\mathrm{MAP}}=12.38 \times I^{-0.39}$ & $2.5<I<40$ \\
\hline
\end{tabular}

than those of Borgo a Mozzano (1 in Fig. 9d) and Vinchiana (5 in Fig. 9d). This result depends on the MAP value. In fact, the MAP obtained for Mutigliano $(1331 \mathrm{~mm})$ is lower than those for Vinchiana $(1376 \mathrm{~mm})$ and Borgo a Mozzano $(1565 \mathrm{~mm})$. The Vinchiana upper threshold is steeper $(\beta=0.40)$ than those for Borgo a Mozzano $(\beta=0.32)$ and Mutigliano $(\beta=0.31)$. This indicates that, for the Vinchiana upper threshold, the rainfall intensity is more important than the cumulative rainfall in discriminating rainfall conditions triggering several or few shallow landslides.

\section{Effect of antecedent rainfall}

Antecedent rainfall plays an important role in the initiation of landslides (Wieczorek, 1987), but its influence is difficult to quantify. It depends on several factors including: local climatic conditions, slope angle, and heterogeneity of soils in terms of physical-mechanical properties and permeability (Aleotti, 2004). For example, coarse soils with large interparticle voids are very permeable. So, antecedent rainfall is not generally a significant factor for triggering debris flows (Corominas and Moya, 1999). On the contrary, in lowpermeability soils antecedent rainfall can be important in reducing soil suction and increasing the pore-water pressure (Aleotti, 2004; D’Amato Avanzi et al., 2004).
Several rainfall variables take antecedent rainfall into consideration, for example the normalized critical rainfall $\left(C_{\text {MAP }}\right.$, Aleotti, 2004) or daily rainfall $(R$, Dahal and Hasegawa, 2008). For shallow landslide events, various authors analyse different time intervals to quantify the rainfall prior to a rainstorm: 3 days (Dahal and Hasegawa, 2008), 5 days (Wieczorek et al., 2000), 10 days (Crozier, 1999; Glade at al., 2000), 15 days (Aleotti, 2004), or 25 days (Terlien, 1998). In order to correlate the rainstorms triggering shallow landslides with antecedent rainfall in the study area, the cumulative rainfall at time intervals of $3,7,15$, and 30 days was analysed and compared with the rainstorm features.

The cumulative event rainfall $E$ as well as the antecedent rainfall $A(D)$ were normalized by MAP. The relationship between normalized rainfall event $E_{\mathrm{MAP}}$ and normalized antecedent rainfall $A(D)$ MAP $\left.\left(A{ }_{D}\right) / \mathrm{MAP}\right)$ of $3,7,15$, and 30 days for the $\mathrm{A}, \mathrm{B}$ and $\mathrm{C}$ events were plotted together (Figs. 11, 12 and 13). For antecedent rainfall of 3 and 7 days the graphs show a pronounced discrimination between events that triggered shallow landslides ( $\mathrm{A}$ and $\mathrm{B}$ events) and those that did not (C events). For 15 and 30 days discrimination is not so evident. In general, the $E_{\mathrm{MAP}} A(D)$ MAP relationship suggests that the $E_{\text {MAP }}$ amount needed for triggering shallow landslides decreases with increasing $A(D)$ MAP. 
Table 5. $E_{\text {MAP }} D$ thresholds for the initiation of shallow landslides for the Borgo a Mozzano, Mutigliano, and Vinchiana rain gauges. Equation: $D$, rainfall duration in hours; $E_{\mathrm{MAP}}$, cumulative event rainfall normalized by MAP. Range: range of validity for the threshold.

\begin{tabular}{llll}
\hline Rain gauge & Type & Equation & Range \\
\hline \multirow{2}{*}{ Borgo a Mozzano } & upper curve & $E_{\mathrm{MAP}}=5.04 \times D^{0.24}$ & $3<D<60$ \\
& lower curve & $E_{\mathrm{MAP}}=2.59 \times D^{0.31}$ & $2<D<90$ \\
\multirow{2}{*}{ Mutigliano } & upper curve & $E_{\mathrm{MAP}}=5.64 \times D^{0.26}$ & $1.5<D<50$ \\
& lower curve & $E_{\mathrm{MAP}}=3.26 \times D^{0.27}$ & $1.5<D<90$ \\
Vinchiana & upper curve & $E_{\mathrm{MAP}}=4.57 \times D^{0.29}$ & $1<D<50$ \\
& lower curve & $E_{\mathrm{MAP}}=2.73 \times D^{0.31}$ & $1<D<80$ \\
\hline
\end{tabular}
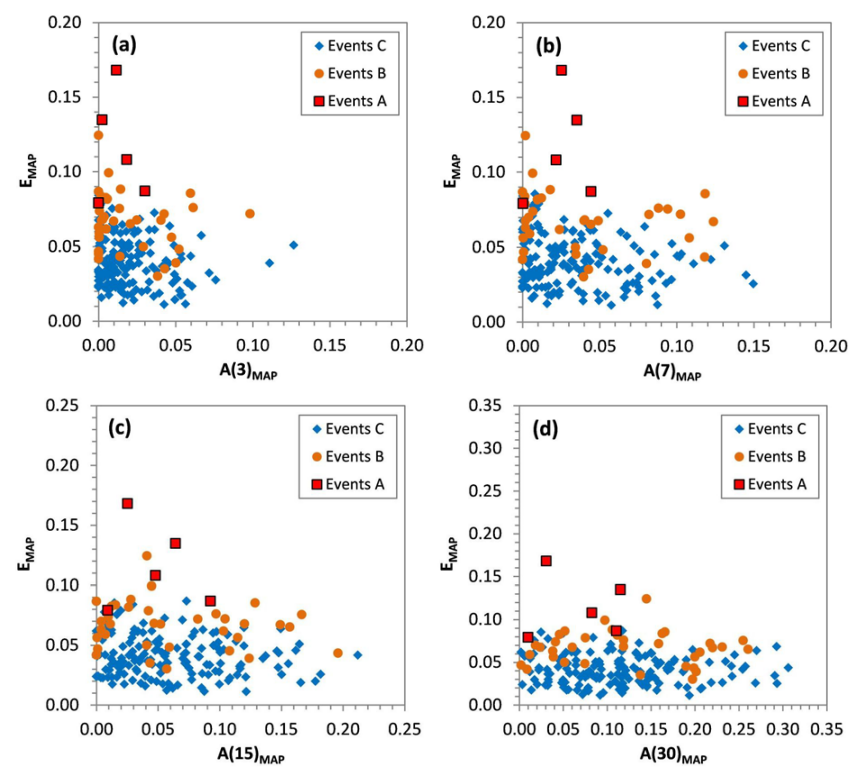

Fig. 11. Relationship between normalized antecedent rainfall $A\left({ }_{D}\right)_{\mathrm{MAP}}$ and normalized event rainfall $E_{\mathrm{MAP}}$ for the Borgo a Mozzano rain gauge. The time intervals considered are of 3 (a), 7 (b), 15 (c) and 30 (d) days.

\section{Discussion}

\subsection{Comparison of rainfall thresholds}

The rainfall ID thresholds obtained for the MSRV (Fig. 8; Table 2) can be compared with regional and local thresholds proposed for Italy (Fig. 15a) and with the global thresholds (Fig. 15b).

Firstly, the thresholds were compared with those proposed by different authors for some areas of north-western Tuscany and Eastern Liguria (Figs. 14 and 15a). The thresholds obtained in this work (1-6 in Fig. 15a) fall in the range of rainfall intensity and duration defined by other thresholds for surrounding areas (7-16 in Fig. 15a). Furthermore, the slope of the threshold curves of the areas of north-western Tuscany (1-12) is similar (Fig. 15a), probably because their climatic, geological, and geomorphologic features are similar.
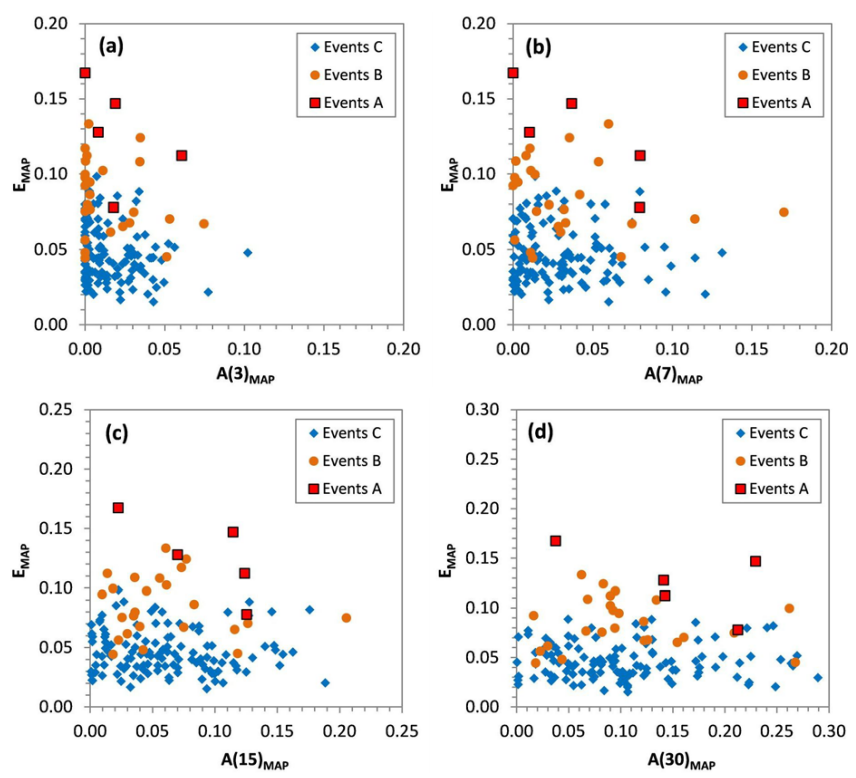

Fig. 12. Relationship between normalized antecedent rainfall $A(D)$ MAP and normalized event rainfall $E_{\mathrm{MAP}}$ for the Mutigliano rain gauge. The time intervals considered are of 3 (a), 7 (b), 15 (c) and $30(\mathbf{d})$ days.

In general, as noted by Govi and Sorzana (1980) and for the Apuan Alps area by Giannecchini (2006), the critical rainfall amount needed to trigger shallow landslides rises with the mean annual precipitation (MAP). For example, the upper curves obtained for the Southern Apuan Alps $(\mathrm{MAP}=1870 \mathrm{~mm})$ and for the Lower Garfagnana $(\mathrm{MAP}=2498 \mathrm{~mm})$ are higher than those obtained in this research (Fig. 15a). An exception is represented by the Carrara Marble Basin (Northern Apuan Alps), where shallow landslides and debris flows usually involve quarry waste. It often shows low permeable or impermeable intervals and lies in valley bottoms and on steep slopes, where landslide susceptibility is higher.

The thresholds obtained in this research were also compared with the ID thresholds proposed for different areas of Italy, including six regional and three local thresholds 

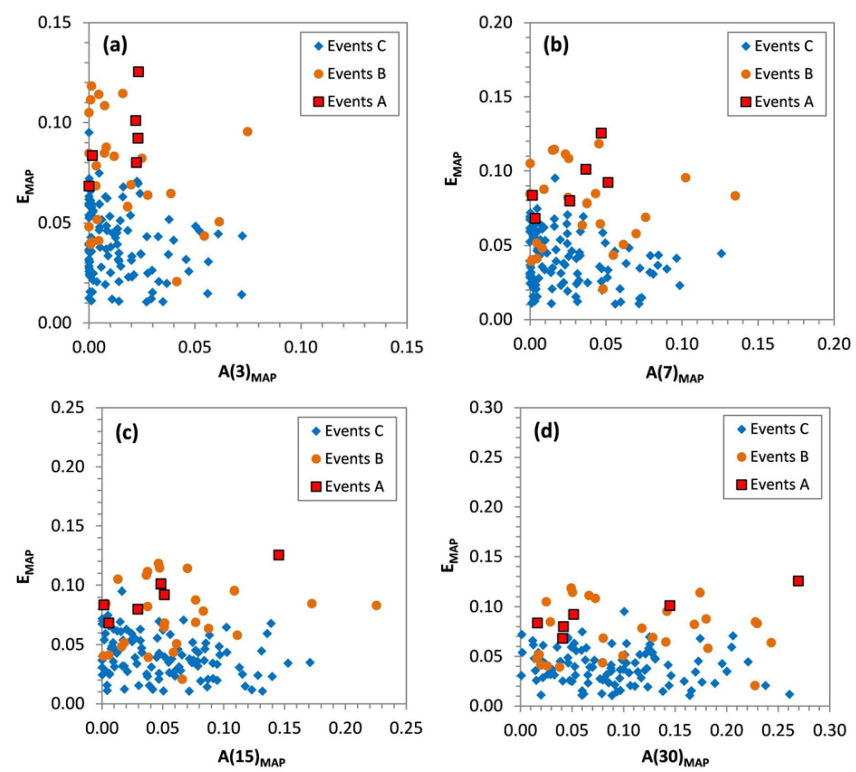

Fig. 13. Relationship between normalized antecedent rainfall $A(D)$ MAP and normalized event rainfall $E_{\text {MAP }}$ for the Vinchiana rain gauge. The time intervals considered are of 3 (a), 7 (b), 15 (c) and 30 (d) days.

(Fig. 15a). A high position, namely a larger mean intensity, is highlighted for the MSRV thresholds (1-6 in Fig. 15a). This is an expected outcome of the climatic conditions of the MSRV, which is characterized by high MAP and high frequency of heavy rainfall. This confirms that each area is in equilibrium with its ordinary climatic conditions, as noted by Govi at al. (1985) for the Piedmont Region.

The thresholds were also compared with the national thresholds for Italy obtained by Brunetti et al. (2010) and some global ID thresholds for shallow landslide occurrence proposed by several authors (Fig. 15b), including Caine (1980), Innes (1983), Jibson (1989), Clarizia et al. (1996), Crosta and Frattini (2001), Cannon and Gartner (2005), and Guzzetti et al. (2008). The comparison shows that the ID thresholds obtained by this study (1-6 in Fig. 15b) are higher than the global thresholds, for the reasons cited above.

Also the $E_{\mathrm{MAP}} I$ thresholds obtained for the MSRV were compared with those proposed for some other areas of Italy (Fig. 16). The upper thresholds for the Borgo a Mozzano (1 in Fig. 16), Mutigliano (3) and Vinchiana (5) rain gauges fall in the range of the normalized event rainfall $E_{\mathrm{MAP}}$ for the Piedmont Region (9-10, Govi et al., 1985) and for the Southern Apuan Alps (7, Giannecchini, 2006). The lower thresholds for Borgo a Mozzano (2), Mutigliano (4) and Vinchiana (6) are less conservative than the lower threshold (8) proposed by Giannecchini (2006) for the Southern Apuan Alps (Fig. 16).

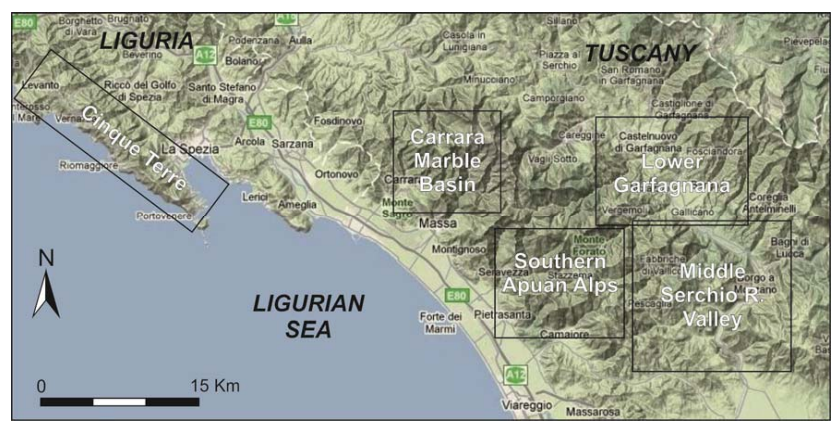

Fig. 14. Area between Liguria and Tuscany where different authors have identified rainfall thresholds (base map by Google Maps, 2010).

\subsection{Threshold validation}

The data used in the elaboration include the whole 19352010 period. Therefore, in order to validate the ID thresholds obtained for the MSRV, the main recent rainfall events from 1 January 2011 to 20 November 2011 were considered. In this period of 2011, shallow landslides did not occur in the study area. Therefore, C-type rainfall events were analysed. Figure 17 compares the rainfall ID thresholds of Borgo a Mozzano (Fig. 17a), Mutigliano (Fig. 17b) and Vinchiana (Fig. 17c) with the ID values of the main 2011 rainfall events.

The main rainfall events recorded at Borgo a Mozzano in 2011 correctly fall below the lower threshold (Fig. 17a), whereas the 4 September 2011 event falls between the lower and the upper threshold curves (intermediate stability field) in the Mutigliano (Fig. 17b) and Vinchiana (Fig. 17c) graphs. Nevertheless, this event did not cause landslides in the study area, but damage to the road network, mainly caused by a lot of fallen trees. This highlights equilibrium limit conditions on slopes, which can be represented by uncertainty in the graphs. Therefore, the results of this validation seem encouraging, even if they are based on a small number of rainfall events.

\subsection{Use of rainfall thresholds}

The thresholds obtained for the MSRV in this work can provide guidance for setting up warning systems and planning emergency actions in the event of heavy rainstorms. Decisions on warning and emergency response can be made on the basis of the comparison of the rainfall forecasts and real-time measurements with the threshold curves. Thus, the threshold curves can help in preparing hazard scenarios, provided that a reliable weather forecast is available.

When the combination of duration and rainfall intensity exceeds the upper threshold curve, tens of shallow landslides can be anticipated (Fig. 8d). If the rainfall events fall between the upper and the lower thresholds (field of intermediate 

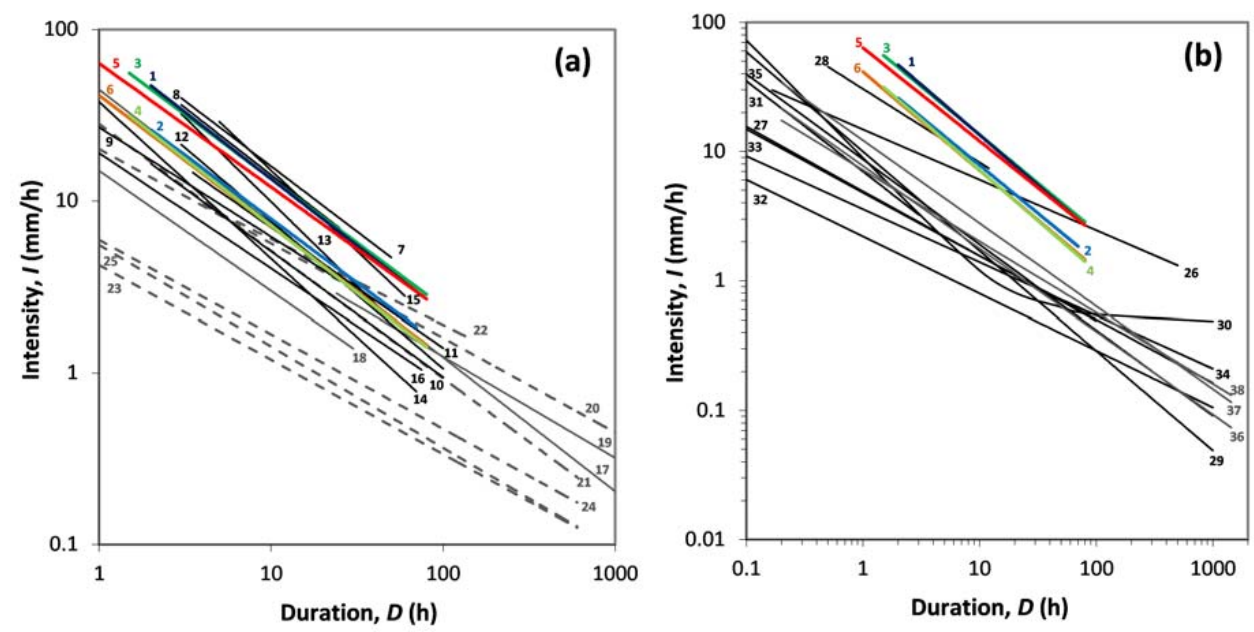

Fig. 15. Comparison between the ID thresholds obtained in this study with some local, regional, national and global thresholds. The thresholds for the MSRV are coloured: dark blue, Borgo a Mozzano upper curve; blue, Borgo a Mozzano lower curve; green, Mutigliano upper curve; light green, Mutigliano lower curve; red, Vinchiana upper curve; orange, Vinchiana lower curve. (a) thresholds for MSRV (colour) and surrounding areas (black), local (gray) and regional (gray dashed) thresholds; source: (1-6), this work; (7), Lower Garfagnana (Governi, 2005); (8-9), Southern Apuan Alps (Giannecchini, 2006); (10-12), Carrara, Fossacava and Rifugio Belvedere (Carrara Marble Basin, unpublished data); (13-14), Portovenere (Cinque Terre area, Giannecchini et al., 2010); (15-16), Levanto (Cinque Terre area, Giannecchini et al., 2010); (17), Valtellina, Lombardy (Cancelli and Nova, 1985); (18), Moscardo Torrent, NE Alps (Marchi et al., 2002); (19), Valzangona, Northern Apennines (Floris et al., 2004); (20), Lombardy (Ceriani et al., 1994 in Bacchini and Zannoni, 2003); (21), Campania (Calcaterra et al., 2000); (22), Piedmont (Aleotti, 2004); (23-25), Abruzzo (Brunetti et al., 2010). (b) global (black) and national (gray) thresholds compared with MSRV (colour) thresholds; source: (1-6), this work; (26), Caine (1980); (27), Innes (1983); (28), Jibson (1989); (29), Clarinza et al. (1996); (30), Crosta and Frattini (2001); (31), Cannon and Gartner (2005); (32-35), Guzzetti et al. (2008); (36-38), National thresholds for Italy (Brunetti et al., 2010).

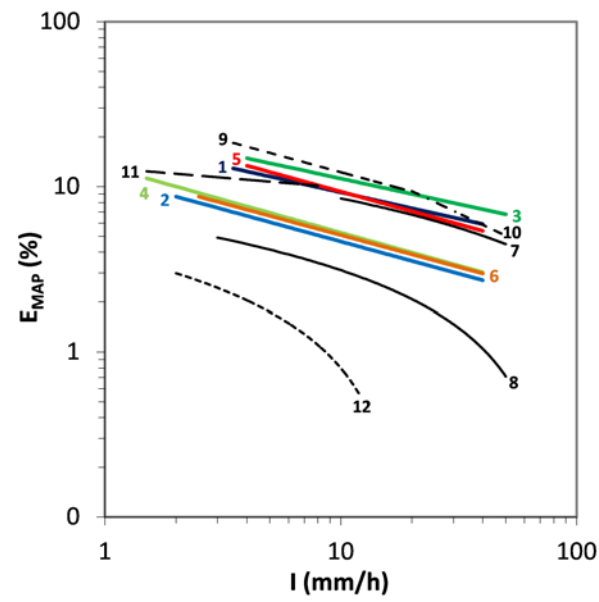

Fig. 16. Comparison between the $\mathrm{E}_{\mathrm{MAP}} \mathrm{I}$ thresholds obtained in this research with the thresholds proposed for other areas of Italy. (1) Borgo a Mozzano upper curve; (2) Borgo a Mozzano lower curve; (3) Mutigliano upper curve; (4) Mutigliano lower curve; (5) Vinchiana upper curve; (6) Vinchiana lower curve; (7) Southern Apuan Alps upper curve (Giannecchini, 2006); (8) Southern Apuan Alps lower curve (Giannecchini, 2006); (9-11) Piedmont Region (Govi et al., 1985); (12) Cancia, Dolomites, North-Eastern Italy (Bacchini and Zannoni, 2003). stability), a few shallow landslides are expected (Fig. 8d). On the basis of a reliable weather forecast, an appropriate scenario can be adopted and an emergency system activated. If a real-time rainfall monitoring system is available, the rainfall evolution can be followed and analyzed step by step.

The threshold curves obtained for the Borgo a Mozzano, Mutigliano and Vinchiana rain gauges are similar (Fig. 8d). Among them, the Vinchiana ones are more conservative. They could be used for testing early warning systems for the entire MSRV, considering its relatively small size and uniformity.

\section{Conclusions}

The intensity-duration (ID) approach allows us to obtain rainfall threshold curves for shallow landslide initiation in the MSRV.

The comparison with other ID thresholds for northwestern Tuscany highlighted the high rainfall thresholds for triggering shallow landslides in the study area. This is linked to the high mean annual precipitation (MAP) and the high frequency of rainstorms hitting the study area, which induce a natural, dynamic equilibrium between climatic features and slopes. 

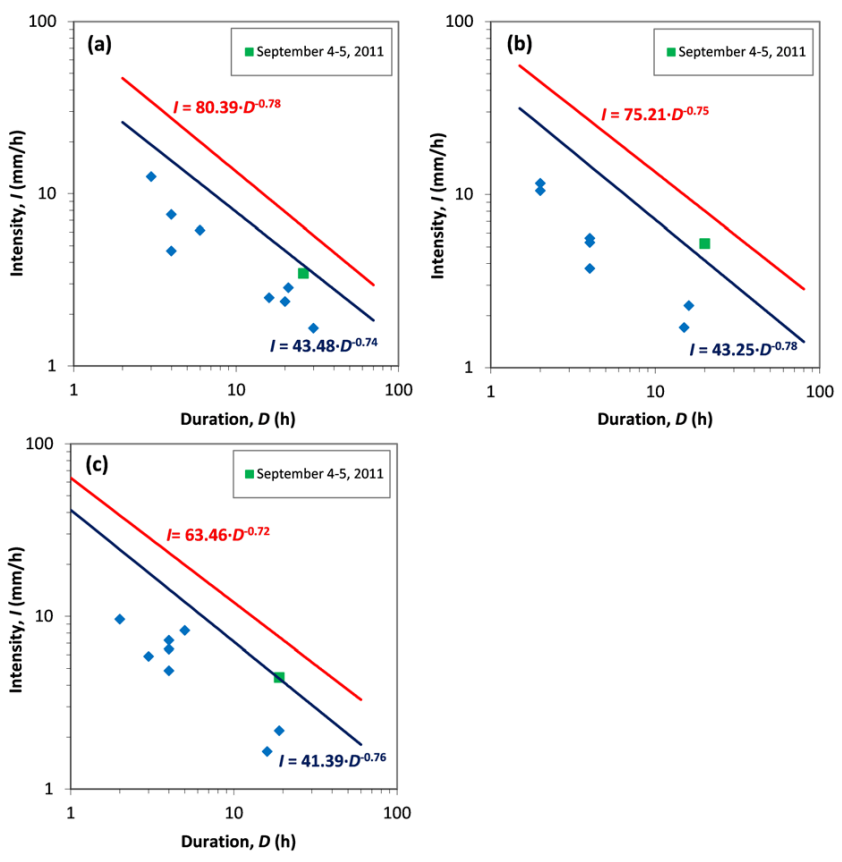

Fig. 17. Comparison between the ID thresholds and the main rainfall events occurring during the 1 January 2011-20 November 2011 period in the MSRV, for the Borgo a Mozzano (a), Mutigliano (b) and Vinchiana (c) rain gauges. The lower (blue) and upper (red) threshold curves are recognizable.

The analysis of the role of the antecedent rainfall in triggering shallow landslides shows that the antecedent period in which the cumulative rainfall should be considered ranges from 3 to 7 days.

Some misclassifications of rainfall events are highlighted in the threshold plots, probably due to imprecise information about landslides and damage up until the 1980s. The threshold validation was performed using rainfall events occurring in 2011, which did not induce shallow landslides and proved that the threshold curves function.

The manual fitting used to construct the threshold curves led to cautionary results. However, mathematical and statistical approaches will be tested and compared with the present results in the next stages of this research.

The threshold curves found by this work can be the basis to set up warning systems, face hydrogeological emergencies, and assess risk. This requires reliable weather forecast systems to be in operation.

The evolution of this research is towards defining risk scenarios for different rainfall amounts, directly linked to the rainfall thresholds. This can be crucial for reliable planning of civil protection strategies.
Acknowledgements. The authors are grateful to the Tuscany Region Hydrologic Service (especially to Luca Pisani) for providing the rainfall data. They wish to thank R. K. Dahal and two other anonymous reviewers, whose suggestions contributed to improving this paper.

Edited by: O. Katz

Reviewed by: R. K. Dahal and two other anonymous referees

\section{References}

Aleotti, P.: A warning system for rainfall-induced shallow failures, Eng. Geol., 73, 247-265, 2004.

Anderson, M. G.: Road-cut slope topography and stability relationships in St. Lucia, West Indies, Appl. Geogr., 3, 104-114, 1983.

Bacchini, M. and Zannoni, A.: Relations between rainfall and triggering of debris-flow: case study of Cancia (Dolomites, Northeastern Italy), Nat. Hazards Earth Syst. Sci., 3, 71-79, doi:10.5194/nhess-3-71-2003, 2003.

Baldacci, F., Cecchini, S., Lopane, G., and Raggi, G.: Le risorse idriche del Fiume Serchio ed il loro contributo all'alimentazione dei bacini idrografici adiacenti, Memorie della Società geologica Italiana, 49, 365-391, 1993.

Bieniawski, Z. T.: Engineering Rock Mass Classification, Wiley, New York, 1989.

Brunetti, M. T., Peruccacci, S., Rossi, M., Luciani, S., Valigi, D., and Guzzetti, F.: Rainfall thresholds for the possible occurrence of landslides in Italy, Nat. Hazards Earth Syst. Sci., 10, 447-458, doi:10.5194/nhess-10-447-2010, 2010.

Caine, N.: The rainfall intensity-duration control of shallow landslides and debris flows, Geogr. Ann. A, 62, 23-27, 1980.

Calcaterra, D., Parise, M., Palma, B., and Pelella, L.: The influence of meteoric events in triggering shallow landslides in pyroclastic deposits of Campania, Italy, in: Proceedings of the 8th International Symposium on Landslides, edited by: Bromhead, E. Dixon, N., and Ibsen, M. L., A. A. Balkema, Cardiff, 1, 209-214, 2000.

Campbell, R. H.: Soil slips, debris flows and rainstorms in the Santa Monica Mountains and vicinity, Southern California, US Geological Survey Professional Paper, 851, 51 pp., 1975.

Cancelli, A. and Nova, R.: Landslides in soil debris cover triggered by rainstorms in Valtellina (central Alps - Italy), in: Proceedings of the 4th International Conference and Field Workshop on Landslides, The Japan Geological Society, Tokyo, 267-272, 1985.

Cannon, S. H.: Regional rainfall-threshold conditions for abundant debris-flow activity, in: Landslides, floods, and marine effects of the storm of January 3-5, 1982, in the San Francisco Bay Region, California, edited by: Ellen, S. D. and Wieczorek, G. F. US Geological Survey Professional Paper, 1434, 35-42, 1988.

Cannon, S. H. and Gartner, J. E.: Wildfire-related debris flow from a hazards perspective, in: Debris flow hazards and related phenomena, edited by: Jakob, M. and Hungr, O., Springer, Berlin, 363-385, 2005.

Cannon, S. H., Gartner, J. E., Wilson R. C., Bowers J. C., and Laber J. L.: Storm rainfall conditions for floods and debris flows from recently burned areas in southwestern Colorado and southern California, Geomorphology, 96, 250-269, 2008.

Carmignani, L., Conti, P., Disperati, L., Fantozzi, P. L., Giglia, G., and Meccheri, M.: Carta Geologica del Parco delle Alpi Apuane, 
Apuan Regional Park, S.El.Ca Ed., Florence, 2000.

Carmignani, L. and Kligfield, R.: Crustal extension in the Northern Apennines: the transition from compression to extension in the Alpi Apuane Core Complex, Tectonics, 9, 1275-1303, 1990.

Castaldini, D., Caredio, F., D’Amato Avanzi, G., Perilli, N., and Puccinelli, A.: Glacial features in the Tuscan-Emilian Apennines (Italy): evidences from the Abetone area, in: The Regione Toscana Project of Geological Mapping, Case Histories and Data Acquisition, edited by: Morini, D. and Bruni, P., Regione Toscana, Firenze, 67-76, 2004.

Ceriani, M., Lauzi, S., and Padovan, N.: Rainfall thresholds triggering debris-flows in the alpine area of Lombardia Region, central Alps - Italy, Proc. Man and Mountain, I Conv. Intern. per la Protezione e lo Sviluppo dell'ambiente montano, Ponte di Legno (BS), 123-139, 1994.

Clarizia, M., Gullà, G., and Sorbino, G.: Sui meccanismi di innesco dei soil slip, in: Proceedings of International Conference on Prevention of Hydro-geological Hazards: The Role of Scientific Research, Alba, Italy, 5-7 November 1996, 1, 585-597, 1996.

Coe, J. A., Kinner, D. A., and Godt, J. W.: Initiation conditions for debris flows generated by runoff at Chalk Cliffs, central Colorado, Geomorphology, 96, 270-297, 2008.

Corominas, J.: Landslides and climate. Keynote lecture, in: Proceedings of the 8th International Symposium on Landslides, edited by: Bromhead, E., Dixon, N., and Ibsen, M. L., A. A. Balkema, Cardiff, 4, 1-33, 2000

Corominas, J. and Moya, J.: Reconstructing recent landslide activity in relation to rainfall in the Llobregat river basin, Eastern Pyrenees, Spain, Geomorphology, 30, 79-93, 1999.

Crosta, G. B. and Frattini, P.: Distributed modelling of shallow landslides triggered by intense rainfall, Nat. Hazards Earth Syst. Sci., 3, 81-93, doi:10.5194/nhess-3-81-2003, 2003.

Crosta, G. B. and Frattini, P.: Rainfall thresholds for triggering soil slips and debris flow, in: Proceedings of the 2nd EGS Plinius Conference on Mediterranean Storms, edited by: Mugnai, A., Guzzetti, F., and Roth, G., Siena, Italy, 16-18 October 2001, 463-487, 2001.

Crozier, M. J.: Prediction of rainfall-triggered landslides: a test of the antecedent water status model, Earth Surf. Proc. Land., 24, 825-833, 1999.

Cruden, D. M. and Varnes, D. J.: Landslide type and processes, in: Landslides investigation and mitigation, edited by: Turner, A. K. and Schuster, R. L., Transportation Research Board Special Report 247, National Research Council, National Academy Press, Washington DC, 36-75, 1996.

D’Amato Avanzi, G., Falaschi, F., Giannecchini, R., and Puccinelli, A.: Soil slip susceptibility assessment using mechanicalhydrological approach and GIS techniques: an application in the Apuan Alps (Italy), Nat. Hazards, 50, 591-603, 2009.

D'Amato Avanzi, G., Giannecchini, R., and Puccinelli, A.: The influence of the geological and geomorphological settings on shallow landslides. An example in a temperate climate environment: the June 19, 1996 event in northwestern Tuscany (Italy), Eng. Geol., 73, 215-228, 2004.

D’Amato Avanzi, G., Galanti, Y., Giannecchini, R., and Puccinelli, A.: Fragility of territory and infrastructures resulting from rainstorms in Northern Tuscany (Italy), in: Proceedings of the 2nd World Landslide Forum, Roma, 3-9 October 2011, Springer-
Verlag, in press, 2012.

Dahal, R. K. and Hasegawa, S.: Representative rainfall thresholds for landslides in the Nepal Himalaya, Geomorphology, 100, 429443, 2008.

Floris, M., Mari, M., Romeo, R. W., and Gori, U.: Modelling of landslide-triggering factors - A case study in the northern Apennines, Italy, Lect. Notes Earth Sci., 104, 745-753, 2004.

Giannecchini, R.: Relationship between rainfall and shallow landslides in the southern Apuan Alps (Italy), Nat. Hazards Earth Syst. Sci., 6, 357-364, doi:10.5194/nhess-6-357-2006, 2006.

Giannecchini, R., Damilano, D., and Puccinelli, A.: Critical rainfall thresholds for triggering rapid shallow landslides in the Eastern Ligurian Riviera (Italy), in: Proceedings of 85th Italian Geological Society National Congress, Pisa, Italy, 6-8 September 2010, 2, 596-597, 2010.

Giannecchini, R., Naldini, D., D'Amato Avanzi, G., and Puccinelli, A.: Modelling of the initiation of rainfall-induced debris flows in the Cardoso basin (Apuan Alps, Italy), Quatern. Int., 171-172, 108-117, 2007.

Glade, T., Crozier, M. J., and Smith, P.: Applying probability determination to refine landslide-triggering rainfall thresholds using empirical "antecedent daily rainfall model", Pure Appl. Geophys., 157, 1059-1079, 2000.

Governi, S.: Valutazione delle soglie pluviometriche critiche per l'innesco di frane rapide nella Media Val di Serchio (LU), Degree thesis, University of Pisa, Italy, 206 pp., 2005.

Govi, M. and Sorzana, P. F.: Landslide susceptibility as function of critical rainfall amount in Piedmont basin (North-Western Italy), Studia Geomorphologica Carpatho-Balcanica, 14, 43-60, 1980.

Govi, M., Mortara, G., and Sorzana P. F.: Eventi idrologici e frane, Geologia Applicata e Idrogeologia, 20, 359-375, 1985.

Guidicini, G. and Iwasa, O. Y.: Tentative correlation between rainfall and landslides in a humid tropical environment, Bull. Int. Assoc. Eng. Geol., 16, 13-20, 1977.

Guzzetti, F.: Landslide fatalities and the evaluation of landslide risk in Italy, Eng. Geol., 58, 89-107, 2000.

Guzzetti, F., Peruccacci, S., Rossi, M., and Stark, C. P.: Rainfall thresholds for the initiation of landslides in central and southern Europe, Meteorol. Atmos. Phys., 98, 239-267, 2007.

Guzzetti, F., Peruccacci, S., Rossi, M., and Stark, C. P.: The rainfall intensity-duration control of shallow landslides and debris flows: an update, Landslides, 5, 3-17, 2008.

Guzzetti, F., Stark, C. P., and Salvati, P.: Evaluation of flood and landslide risk to the population of Italy, Environ. Manage., 36, 15-36, 2005.

Haigh, M. J., Rawat, J. S., and Bartarya, S. K.: Environmental correlations of landslide frequency along new highways in the Hymalaya - preliminary results, Catena, 15, 539-553, 1988.

Innes, J. L.: Debris flows, Prog. Phys. Geogr., 7, 469-501, 1983.

Iverson, R. M.: Landslide triggering by rain infiltration, Water Resour. Res., 36, 1897-1910, 2000.

Jibson, R. W.: Debris flow in southern Porto Rico, Geological Society of America, 236, 29-55, 1989.

Larsen, M. C. and Parks, J. E.: How wide is a road? The association of roads and mass-wasting in a forested montane environment, Earth Surf. Proc. Land., 22, 835-848, 1997.

Marchi, L., Arattano, M., and Deganutti, A. M.: Ten years of debrisflow monitoring in the Moscardo Torrent (Italian Alps), Geomorphology, 46, 1-17, 2002. 
Montgomery, D. R. and Dietrich, W. E.: A physically based model for the topographic control on shallow landsliding, Water Resour. Res., 30, 1153-1171, 1994.

Puccinelli, A., D’Amato Avanzi, G., and Perilli, N.: Carta Geologica d'Italia alla scala 1:50.000. Foglio 250 Castelnuovo di Garfagnana, available at: http://www.isprambiente.gov.it/media/ carg/250_Castelnuovo/Foglio.html, in press, 2012.

Reichenbach, P., Cardinali, M., De Vita, P., and Guzzetti, F.: Regional hydrological thresholds for landslides and floods in the Tiber River Basin (central Italy), Environm. Geol., 35, 146-159, 1998.

Saito, H., Nakayama, D., and Matsuyama, H.: Relationship between the initiation of a shallow landslide and rainfall intensityduration thresholds in Japan, Geomorphology, 118, 167-175, 2010.

Terlien, M. T. J.: The determination of statistical and deterministic hydrological landslide-triggering thresholds, Environ. Geol., 35, 124-130, 1998.
Wieczorek, G. F.: Effect of rainfall intensity and duration on debris flows in central Santa Cruz Mountains, California, in: Debris Flows/Avalanches: Processes, Recognition and Mitigation, edited by: Costa, J. E. and Wieczorek, G. F., Reviews in Engineering Geology, Geological Society of America, 7, 23-104, 1987.

Wieczorek, G. F., Morgan, B. A., and Campbell, R. H.: Debris flow hazards in the Blue Ridge of Central Virginia, Environ. Eng. Geosci., 6, 3-23, 2000.

Wieczorek, G. F. and Glade, T.: Climatic factors influencing occurrence of debris flows, in: Debris flow hazards and related phenomena, edited by: Jakob, M. and Hungr, O., Berlin Heidelberg, Springer, 325-362, 2005.

Wilson, R. C. and Wieczorek, G. F.: Rainfall thresholds for the initiation of debris flow at La Honda, California, Environ. Eng. Geosci., 1, 11-27, 1995.

Wu, W. and Sidle, R. C.: A distributed slope stability model for steep forested basins, Water Resour. Res., 31, 2097-2110, 1995. 